\title{
Hydrochemical and Isotopic Characteristics of the Basement Aquifer in the Wadi Fira Area, Eastern Chad
}

\author{
Hamza B. Mahamat1,2, Mathieu Le Coz ${ }^{1}$, Hamit Abderamane ${ }^{3}$, Paul Sardini' ${ }^{1}$, Moumtaz Razack ${ }^{*}$ \\ ${ }^{1}$ University of Poitiers, Poitiers, France \\ ${ }^{2}$ Departement of Geology, Polytechnic Institute of Mongo, N’Djamena, Chad \\ ${ }^{3}$ Departement of Geology, Faculty of Exact and Applied Sciences, University of N'Djamena, N'Djamena, Chad \\ Email: *moumtaz.razack@univ-poitiers.fr
}

How to cite this paper: Mahamat, H.B., Coz, M.L., Abderamane, H., Sardini, P. and Razack, M. (2017) Hydrochemical and Isotopic Characteristics of the Basement Aquifer in the Wadi Fira Area, Eastern Chad. Journal of Water Resource and Protection, 9, 1688-1708.

https://doi.org/10.4236/jwarp.2017.913105

Received: September 25, 2017

Accepted: December 26, 2017

Published: December 29, 2017

Copyright (c) 2017 by authors and Scientific Research Publishing Inc. This work is licensed under the Creative Commons Attribution International License (CC BY 4.0).

http://creativecommons.org/licenses/by/4.0/

\begin{abstract}
The Wadi-Fira region in eastern Chad is facing dramatic water supply problems, related to the climatic semi-arid context and the reception of refugees from the Darfour, which has increased the local population by $22 \%$ these last years. Expansion of agglomerations (temporary new towns), development of agricultural and pastoral practices together with the augmentation of the population have led to dramatic water needs. The basement aquifer of Wadi-Fira constitutes the main source of water supply. However, little is known about this system. Within this context, this work aims at better understanding and identifying hydrogeochemical processes and their relations to groundwater quality within this complex environment, and groundwater recharge mechanisms. 31 groundwater samples were collected at two sites, Am Zoer and Guereda-Iriba, from hand dug wells and deep wells. Major chemical elements were analyzed on all samples and stables isotopes (oxygen-18 and deuterium) on 17 samples. Various methods were used to interpret the hydrochemical data (descriptive and multivariate statistics, Piper and Schoeller diagrams, scatter plots, minerals saturation indices). The stable isotopes were interpreted using conventional IAEA methods. The results permitted to differentiate the laterite reservoir from the deep fractured reservoir. The main process controlling groundwater mineralization is water-rocks interaction and natural minerals dissolution. Ion exchanges, evaporation and anthropogenic activities have also a moderate impact on groundwater quality. Based on isotopes data, it is concluded that groundwater in the basement aquifer is related with modern rainfall. These results provide further insights into this basement aquifer, which is a vital resource for the region of Wadi-Fira.
\end{abstract}




\section{Keywords}

Wadi-Fira, Chad, Basement Aquifer, Hydrochemistry, Stable Isotopes

\section{Introduction}

The Wadi-Fira region in eastern Chad, adjacent to Sudan (Figure 1), is located in an arid environment, exposed to the climate changes, where crystalline basement is mainly exposed. This region is regularly faced with recurring problems of water supply. This situation is linked to the climatic context of this region with a rather low rainfall, but also to the lack of knowledge about the basement aquifer.

However, the basement aquifer of Wadi-Fira constitutes the main source of water supply for the populations of this region. The aquifer system has two main types of reservoirs, the alterites reservoir and the fractured reservoir. Most of the underground water resources exploited by deep wells and hand dug wells are located in alterites and basement fractured rocks. Sedimentary formations play a negligible role.

In 2003 , the Wadi-Fira region hosted $\approx 201,000$ refugees from Darfur out of a total of $\approx 924,000$ residents that is $22 \%$ of the population. This migratory flow led to an expansion of agglomerations (temporary new towns), an increase in agricultural and pastoral practices. The groundwater of the crystalline system is thus now heavily exploited to meet the dramatically increasing water requirements in recent years.

The rational exploitation of this vital resource requires a prior assessment of

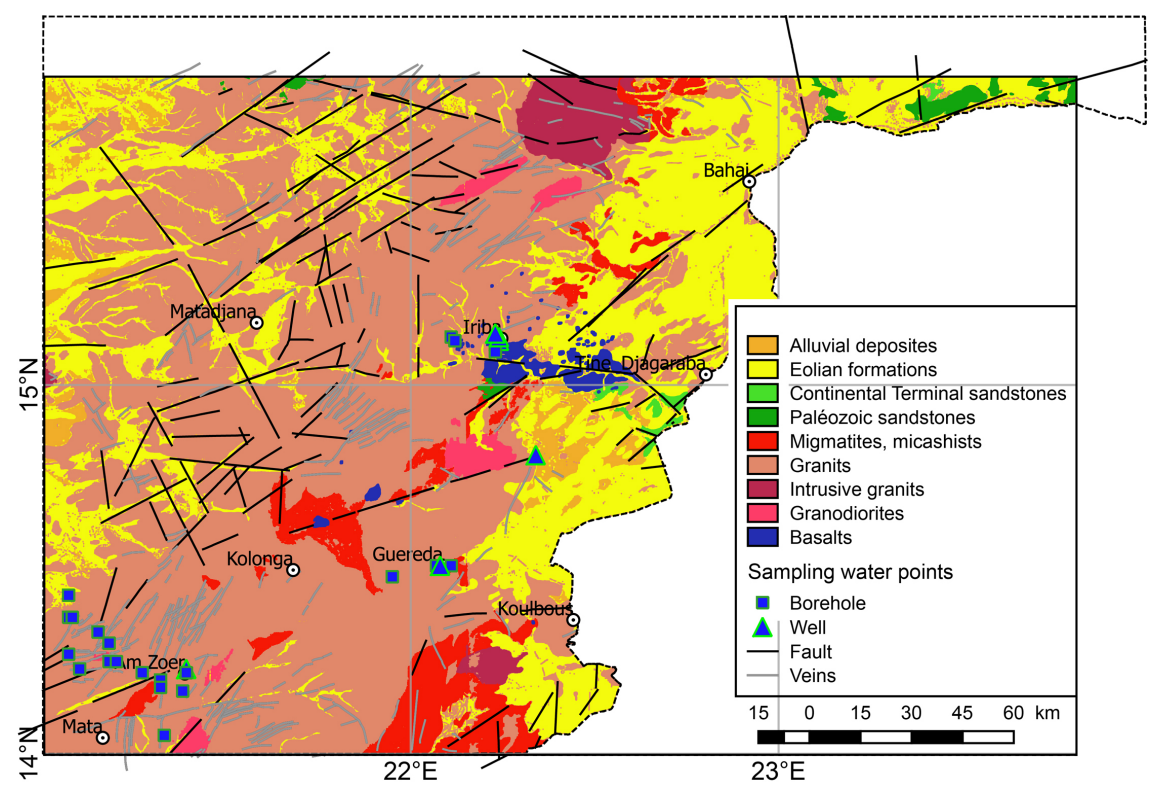

Figure 1. Location and geological setting of the study site. Wadi-Fira region (Eastern Chad). 
the processes of mineralization of the groundwater in order not to degrade its quality by a disorderly overexploitation.

Within this framework, the present investigation aims at better understanding and identifying hydrogeochemical processes and their relations to groundwater quality within this complex environment, and groundwater recharge mechanisms.

The geological formations encountered in the study area are mainly granitoids, schists, migmatites and volcano-sedimentary formations (basalts and alluvium) covering the crystalline basement. Two regions were sampled to conduct this work, the Am Zoer region and the Guereda-Iriba region.

\section{Geological and Hydrogeological Framework}

The study area lies between latitudes $14^{\circ}$ and $16^{\circ}$ North, and longitudes $21^{\circ}$ and $23^{\circ}$ East. It covers an area of approximately $50,000 \mathrm{~km}^{2}$. It is characterized by a Sahelo-Saharan climate, with a great spatial and temporal variability in precipitation, i.e. 150 to $400 \mathrm{~mm}$ of rain per year, between the North and the South. Most of the rainfall is concentrated over two months, between July and August. The Am Zoer site is located in the south-west, and that of Guereda-Iriba in the northeast (Figure 1). The particularities of these two contexts will be analyzed from the hydrogeochemical point of view related to the aspect of the water resource.

The geological context of the study area (Figure 1) was elaborated from the geological map of Niéré at 1/500,000 [1].

The formations of the Precambrian basement identified in Chad, of which the Ouaddai massif forms part, covers between $15 \%$ and $20 \%$ of the territory of the country [2]. The formations encountered are granitoids, metamorphic rocks (schists, quartzites, micaschists, gneiss, green rocks and migmatites) and volcano-sedimentary formations. The granitoids are composed of granodiorites and granites that are exposed on most parts of the basement of the Ouaddai. The volcanic formations occur in basaltic flows along the wadi Absounout near Iriba, or in isolated pitons with circular base about $200 \mathrm{~m}$ in diameter and with steep slope. The sedimentary formations consist of the Palaeozoic (Cambrian) sandstones, the Continental Terminal sandstones and alluvial formations (sand, clay, silt).

From recent results, it is observed that in basement hard rocks, aquifers are located within the first tens of meters in the rocks [3] [4] [5]. The typical vertical profile comprises from top to bottom: i) The laterite layer with a few meters thickness, ii) The alterite (or regolith) layer, a few tens of meters thick, derived from the weathering of the basement rocks; iii) The fractured layer which consists of the massive rocks. The fracture network mainly results from the tectonic activity in the region, but also from the weathering process itself [6] [7].

In the Wadi-Fira study area, groundwater is exploited by shallow large-diameter wells (average depth $\approx 10 \mathrm{~m}$ ) dug in the alterites and deeper wells penetrating the fractured aquifer (mean depth $\approx 45 \mathrm{~m}$ ). 
The hydrodynamic properties are very variable in space, showing the strong heterogeneity of this system. Transmissivities estimated by pumping tests on deep wells range between $1.9 \times 10^{-6}$ to $8.8 \times 10^{-4} \mathrm{~m}^{2} / \mathrm{h}$. Discharge rates are generally low. More than $80 \%$ of wells have discharge rates between 0.5 and $5 \mathrm{~m}^{3} / \mathrm{h}$. Flow rates exceeding $10 \mathrm{~m}^{3} \cdot \mathrm{h}^{-1}$ were obtained at Diker (Am Zoer site) and on two wells at Guereda. Such high discharges are linked respectively to a thick sedimentary layer $(20$ to $40 \mathrm{~m}$ ) and a well-developed (10 and $26 \mathrm{~m}$ ) weathered and/or fractured horizon.

The piezometric map is reported in Figure 2. This map does not differentiate the laterite reservoir from the fractured rocks reservoir. Given the scale of the study area, a continuous system can be assumed. Interpretation of the map indicates that groundwater is mainly drained towards rivers beds.

\section{Sampling and Analytical Procedures}

Two sampling campaigns were conducted in 2011 and 2015 for a total of 31

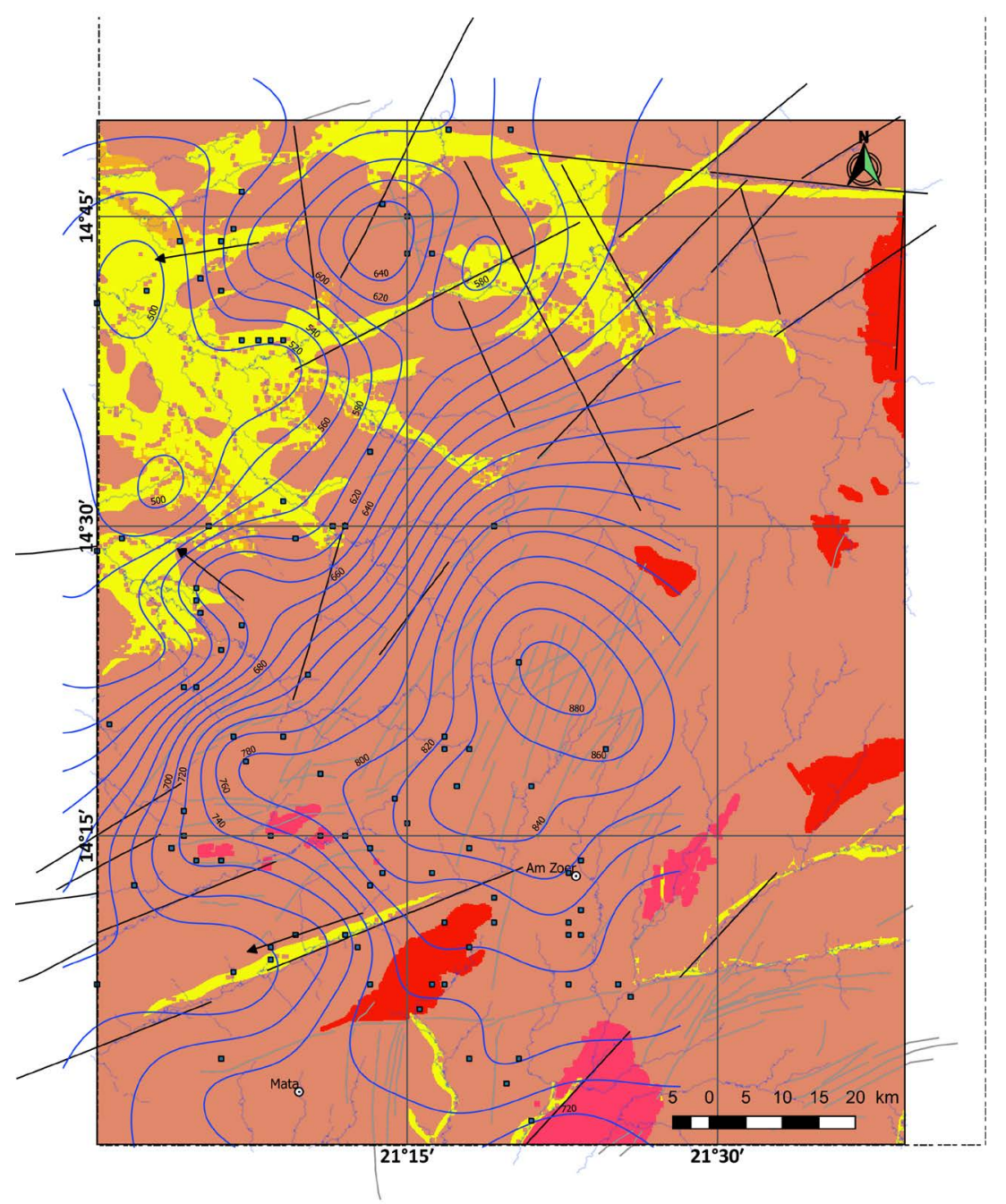

Figure 2. Piezometric map of the study area. 
groundwater samples. The first campaign involved 15 deep wells. The analyses were carried out at the National Laboratory of Water Analysis (LNAE) in Ndjamena (Chad). The second field mission in July 2015 resulted in the sampling of 16 water samples from boreholes (9) and dug wells (7). The chemical and isotopic analyzes were carried out at the Center of Hydrogeology and Geothermics (CHYN) of the University of Neuchâtel in Switzerland.

During both field missions, the physical parameters (electrical conductivity, $\mathrm{pH}$ and temperature) of the groundwater were measured in situ. The data of the conductimeter during these two campaigns proved unfortunately wrong.

Other complementary parameters were also measured, the location and altitude of the water points using a Garmin GPS, the piezometric level and the depth of the wells respectively by a piezometric probe and a decametric tape.

Analyzes of the major ions, cations and anions were carried out respectively by ion chromatography Dionex DX-120 and Dionex-ICS-1600. The determination of the bicarbonate ion $\left(\mathrm{HCO}_{3}^{-}\right)$was carried out by the titrimetry method using an apparatus of the Metrohm 805 Dosimat type. The quality of the analyses was verified by the calculation of the ion balance.

The isotopic analyzes were carried out only on the samples collected during the $2^{\text {nd }}$ campaign in 2015. The stable isotopes contents of the water molecule are measured by the Picarro L2140-i analyzer, which performs simultaneous measurements of $\delta^{18} \mathrm{O}$ and $\delta^{2} \mathrm{H}$ with an accuracy of $\pm 0.0015 \%$.

All stable isotopic composition $\left({ }^{18} \mathrm{O}\right.$ and $\left.{ }^{2} \mathrm{H}\right)$ are reported in standard $\delta \%$ notation (part per thousand versus VSMOW (Vienna Standard Mean Ocean Water)) as follows:

$$
\delta \%_{0}=[(\text { Rsample } / \text { Rstandard })-1] \times 1000
$$

where Rsample and Rstandard represent the ratio of heavy to light isotopes of the samples and standard, respectively [8].

\section{Interpretative Methods}

The results of the physico-chemical and isotopic analyzes carried out on the 31 groundwater samples are interpreted using statistical, graphical and hydrogeochemical methods. Statistical interpretations were performed using box-plots, correlation matrice and Principal Component Analysis (PCA).

The hydrochemical classification of water is developed using Piper's trilinear diagram [9]. The study of hydrochemical processes is based on the calculation of the saturation indices and scatter diagrams of chemical elements.

The Phreeqc geochemical program allowed to evaluate the saturation indices, to characterize the geochemical processes at the origin of the mineralization of groundwater.

Isotopic data on stable isotopes (oxygen-18 and deuterium) in groundwater have been interpreted using conventional IAEA methods [10].

The application of all these different methods to the hydrochemical and isotope data allowed to characterize the mechanisms of mineralization of ground- 
water and the recharge processes in the basement aquifer of the Wadi-Fira area.

\section{Groundwater Chemistry}

\subsection{Descriptive Statistics}

The physico-chemical data of the groundwaters samples are reported in Table 1.

Table 1. Hydrochemical data from samples collected in the field at the 2 sites, Am-Zoer (AZ) and Guereda-Iriba (GI). P: hand dug wells; F: deep wells.

\begin{tabular}{|c|c|c|c|c|c|c|c|c|c|c|c|c|c|c|}
\hline Name & Long E & Lat $\mathrm{N}$ & Depth (m) & $\mathrm{T}^{\circ} \mathrm{C}$ & $\mathrm{pH}$ & $\mathrm{Ca}^{2+}$ & $\mathrm{Mg}^{2+}$ & $\mathrm{Na}^{+}$ & $\mathrm{K}^{+}$ & $\mathrm{HCO}_{3}^{-}$ & $\mathrm{Cl}^{-}$ & $\mathrm{SO}_{4}^{2-}$ & $\mathrm{F}^{-}$ & $\mathrm{NO}_{3}^{-}$ \\
\hline AZ-F1 & 21.18 & 14.25 & 31.0 & 27.6 & 7.2 & 44.0 & 11.0 & 20.0 & 2.0 & 165.9 & 25.0 & 2.0 & 1.0 & 18.2 \\
\hline AZ-F2 & 21.2 & 14.25 & 33.0 & 27.6 & 7.1 & 61.0 & 11.5 & 30.0 & 3.0 & 244.0 & 25.0 & 13.0 & 1.0 & 20.0 \\
\hline AZ-F3 & 21.32 & 14.2 & 53.0 & 27.4 & 8.0 & 57.8 & 3.9 & 39.0 & 3.9 & 173.2 & 25.0 & 46.0 & 1.3 & 30.0 \\
\hline AZ-F4 & 21.27 & 14.22 & 70.0 & 30.7 & 8.7 & 56.0 & 4.9 & 32.0 & 3.2 & 195.2 & 30.0 & 13.0 & 0.8 & 20.2 \\
\hline AZ-F5 & 21.33 & 14.05 & 33.0 & 26.5 & 7.1 & 32.8 & 10.0 & 36.0 & 3.6 & 124.0 & 11.0 & 2.0 & 1.1 & 59.0 \\
\hline AZ-F6 & 21.32 & 14.18 & 51.0 & 32.9 & 7.1 & 88.8 & 0.5 & 24.0 & 2.4 & 317.2 & 30.0 & 2.0 & 1.4 & 20.2 \\
\hline AZ-F7 & 21.1 & 14.23 & 41.0 & 29.3 & 8.8 & 44.7 & 10.0 & 18.0 & 1.9 & 165.9 & 17.0 & 11.0 & 1.0 & 15.0 \\
\hline AZ-F8 & 21.15 & 14.33 & 41.0 & 30.4 & 7.6 & 33.6 & 8.7 & 27.0 & 5.2 & 159.8 & 15.0 & 15.0 & 1.0 & 2.7 \\
\hline AZ-F9 & 21.18 & 14.3 & 65.0 & 31.9 & 7.8 & 26.4 & 5.8 & 30.0 & 6.0 & 122.0 & 23.0 & 27.0 & 0.1 & 2.1 \\
\hline AZ-F10 & 21.18 & 14.3 & 59.0 & 32.4 & 7.6 & 42.4 & 4.6 & 28.0 & 5.0 & 170.8 & 20.0 & 20.0 & 0.2 & 3.4 \\
\hline AZ-F11 & 21.07 & 14.37 & 45.0 & 25.9 & 8.8 & 52.0 & 6.8 & 28.0 & 3.0 & 190.3 & 13.0 & 15.0 & 1.0 & 30.0 \\
\hline AZ-F12 & 21.08 & 14.37 & 45.0 & 28.0 & 8.5 & 79.2 & 30.0 & 42.0 & 9.0 & 366.0 & 45.0 & 54.0 & 1.0 & 2.3 \\
\hline AZ-F13 & 21.08 & 14.37 & 43.0 & 25.9 & 8.8 & 53.6 & 8.0 & 22.0 & 2.0 & 195.0 & 15.0 & 9.0 & 1.0 & 14.0 \\
\hline AZ-F14 & 21.38 & 14.17 & 29.0 & 30.4 & 8.9 & 69.6 & 3.4 & 25.0 & 2.5 & 219.6 & 30.0 & 15.3 & 1.3 & 10.1 \\
\hline AZ-F15 & 21.07 & 14.27 & 31.0 & 29.6 & 8.7 & 59.2 & 16.0 & 34.0 & 2.4 & 317.0 & 10.0 & 17.0 & 1.0 & 4.4 \\
\hline AZ-F16 & 21.39 & 14.22 & 37.0 & 28.5 & 6.1 & 24.5 & 7.3 & 18.2 & 1.1 & 125.2 & 12.1 & 9.6 & 1.4 & 9.4 \\
\hline AZ-F17 & 21.39 & 14.22 & 35.0 & 29.8 & 5.9 & 47.5 & 13.3 & 29.2 & 2.5 & 131.8 & 24.2 & 20.9 & 1.2 & 113.1 \\
\hline AZ-F18 & 21.07 & 14.43 & 37.8 & 27.5 & 7.2 & 25.3 & 5.1 & 32.2 & 1.6 & 125.2 & 3.7 & 10.0 & 1.3 & 26.4 \\
\hline AZ-P1 & 21.27 & 13.98 & 13.0 & 27.5 & 7.0 & 69.5 & 22.9 & 49.9 & 2.6 & 430.1 & 7.9 & 15.6 & 1.1 & 21.6 \\
\hline AZ-P2 & 21.39 & 14.23 & 5.6 & 27.0 & 5.6 & 13.9 & 3.7 & 7.0 & 6.4 & 71.1 & 3.2 & 4.6 & 0.3 & 26.6 \\
\hline GI-P3 & 22.24 & 15.12 & 13.7 & 24.7 & 6.6 & 24.1 & 4.9 & 12.6 & 4.4 & 132.1 & 2.9 & 6.2 & 0.4 & 8.1 \\
\hline GI-P4 & 22.24 & 15.13 & 11.9 & 26.1 & 6.5 & 28.7 & 7.0 & 21.3 & 4.5 & 185.9 & 2.7 & 3.0 & 0.5 & 2.9 \\
\hline GI-P5 & 22.23 & 15.14 & 9.6 & 26.1 & 5.2 & 22.8 & 5.7 & 10.7 & 8.3 & 79.3 & 12.7 & 15.1 & 0.3 & 28.0 \\
\hline GI-P6 & 22.34 & 14.81 & 10.5 & 26.5 & 5.1 & 14.6 & 4.7 & 9.6 & 4.5 & 78.0 & 4.2 & 7.0 & 0.3 & 24.4 \\
\hline GI-P7 & 22.08 & 14.51 & 6.9 & 26.1 & 4.6 & 10.6 & 3.0 & 6.3 & 6.3 & 53.4 & 3.6 & 5.3 & 0.3 & 17.2 \\
\hline GI-F19 & 22.23 & 15.09 & 42.0 & 27.8 & 6.7 & 27.9 & 9.0 & 33.0 & 2.3 & 199.5 & 4.0 & 7.2 & 0.5 & 17.5 \\
\hline GI-F20 & 22.11 & 15.13 & 62.0 & 30.9 & 6.0 & 49.4 & 12.9 & 47.9 & 1.8 & 312.2 & 6.5 & 13.2 & 2.2 & 17.2 \\
\hline GI-F21 & 22.12 & 15.12 & 39.0 & 29.5 & 5.9 & 32.4 & 9.7 & 31.7 & 1.3 & 224.5 & 3.6 & 5.8 & 1.6 & 7.6 \\
\hline GI-F22 & 22.07 & 14.51 & 66.0 & 16.5 & 5.1 & 14.9 & 3.4 & 16.1 & 2.3 & 103.0 & 3.0 & 4.1 & 1.4 & 5.7 \\
\hline GI-F23 & 22.11 & 14.51 & 35.0 & 28.7 & 6.2 & 48.0 & 13.7 & 92.1 & 0.8 & 423.5 & 11.1 & 11.9 & 2.9 & 11.5 \\
\hline GI-F24 & 21.95 & 14.48 & 58.0 & 28.0 & 6.5 & 65.1 & 18.3 & 32.1 & 2.6 & 282.1 & 23.6 & 13.7 & 1.1 & 51.6 \\
\hline
\end{tabular}


The descriptive statistics (average, variance, coefficient of variation) are reported in Table 2. The groundwater samples are of low overall mineralization. The average mineralization is $336 \mathrm{mg} / \mathrm{l}$ and is in the range of 106 to $628 \mathrm{mg} / \mathrm{l}$, showing that the groundwater in the study area is fresh.

The $\mathrm{pH}$ of the groundwater, for both hand dug wells and deep wells ranges between 4.6 and 8.9 with an average of 7.0. More than half of the $\mathrm{pH}$ values (51\%) are in the range 5.5 - 7.5. Such intermediate natural-water $\mathrm{pH}$ values implies a balance between the production of $\mathrm{H}^{+}$ions from the dissociation of weak acids, and $\mathrm{H}^{+}$(and $\mathrm{CO}_{2}$ ) consumption by weathering reactions, as the weathering of albite (Na-feldspar) to kaolinite [11].

$$
2 \mathrm{NaAlSi}_{3} \mathrm{O}_{8}+2 \mathrm{CO}_{2}+11 \mathrm{H}_{2} \mathrm{O} \rightarrow \mathrm{Al}_{2} \mathrm{Si}_{2} \mathrm{O}_{5}(\mathrm{OH})_{4}+2 \mathrm{Na}^{+}+4 \mathrm{H}_{4} \mathrm{SiO}_{4}+2 \mathrm{HCO}_{3}^{-}(1)
$$

The weak acids involved in these processes are carbonic acid and organic acids such as fulvic acid [11]. These weak acids are the cause which provokes the weathering of silicate and alumino-silicate minerals within such basement environment.

Higher $\mathrm{pH}$ values are also observed in the study area with values in the range 7.5 - 8.5 common in groundwaters in hard rocks (basalt and granite). The maximum observed $\mathrm{pH}$ value for groundwaters is 8.9. High $\mathrm{pH}$ values occur in waters whose composition is dominated by minerals such as silicates and aluminosilicates, which tend to raise the $\mathrm{pH}$ [11]. Groundwaters with $\mathrm{pH}$ values greater than 9.0 are classified as'rock-dominated' [11], meaning that they are likely not to be recharged very fast. All $\mathrm{pH}$ values higher that 7.5 characterize deep wells in the study area, showing that groundwater recharge in such sites is slower.

The groundwater temperature varies from $16^{\circ} \mathrm{C}$ to $33^{\circ} \mathrm{C}$ with an average of $28^{\circ} \mathrm{C}$. These temperatures are close to the air temperature in the region of $29^{\circ} \mathrm{C}$, showing that recharge takes place by infiltration of rainfall, in the absence of

Table 2. Descriptive statistics of the hydrochmical parameters. CV: coefficient of variation; SD: standard deviation.

\begin{tabular}{ccccccc}
\hline Parameter & Minimum & Maximum & Average & S.D. & CV \% & $\begin{array}{c}\text { WHO } \\
\text { Standard }\end{array}$ \\
\hline $\mathrm{Ca}^{2+}(\mathrm{mg} / \mathrm{l})$ & 10.6 & 88.8 & 42.6 & 20.4 & 47.9 & - \\
$\mathrm{Mg}^{2+}(\mathrm{mg} / \mathrm{l})$ & 0.5 & 30.0 & 9.0 & 6.3 & 69.7 & $50-500$ \\
$\mathrm{Na}^{+}(\mathrm{mg} / \mathrm{l})$ & 6.3 & 92.1 & 28.5 & 16.1 & 56.5 & $150-200$ \\
$\mathrm{~K}^{+}(\mathrm{mg} / \mathrm{l})$ & 0.8 & 9.0 & 3.5 & 2.0 & 58.2 & No-12 \\
$\mathrm{Cl}^{-}(\mathrm{mg} / \mathrm{l})$ & 2.7 & 45.0 & 14.9 & 10.9 & 72.6 & $200-250$ \\
$\mathrm{SO}_{4}^{2-}(\mathrm{mg} / \mathrm{l})$ & 2.0 & 54.0 & 13.4 & 11.5 & 86.4 & 250 \\
$\mathrm{HCO}_{3}^{-}(\mathrm{mg} / \mathrm{l})$ & 53.4 & 430.1 & 196.2 & 99.1 & 50.5 & - \\
$\mathrm{NO}_{3}^{-}(\mathrm{mg} / \mathrm{l})$ & 2.1 & 113.1 & 20.7 & 21.7 & 105.2 & 50 \\
$\mathrm{~F}^{-}(\mathrm{mg} / \mathrm{l})$ & 0.1 & 2.9 & 1.0 & 0.6 & 58.7 & 1.5 \\
$\mathrm{~T}^{\circ}\left({ }^{\circ} \mathrm{C}\right)$ & 16.5 & 32.9 & 28.0 & 3.0 & 10.6 & \\
$\mathrm{pH}$ & 4.6 & 8.9 & 7.0 & 1.3 & 18.0 & \\
\hline
\end{tabular}


very deep circulations.

An analysis of the hydrochemical data, carried out using Box-plots, is shown in Figure 3. The purpose of this plot is to demonstrate a possible differentiation between subsurface groundwater sampled in wells dug in alterites and the deep groundwater sampled in wells penetrating the fractured crystalline reservoir. The mean values of the variables are also reported in Table 3.

The box-plot (Figure 3) compares the parameters of waters from the boreholes and dug wells. This results in significant differences in the values of $\mathrm{T}^{\circ} \mathrm{C}$, $\mathrm{pH}, \mathrm{Ca}^{2+}, \mathrm{Na}^{+}, \mathrm{K}^{+}, \mathrm{Cl}^{-}, \mathrm{HCO}_{3}^{-}, \mathrm{SO}_{4}^{2-}$, and $\mathrm{F}^{-}$.
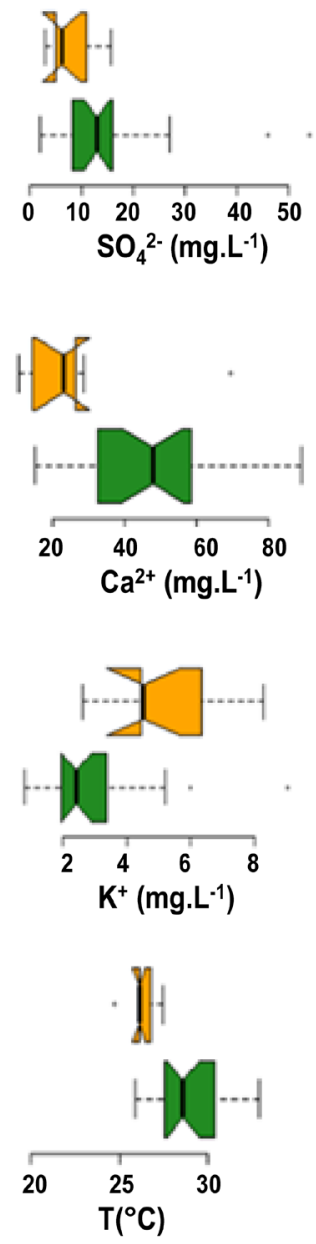
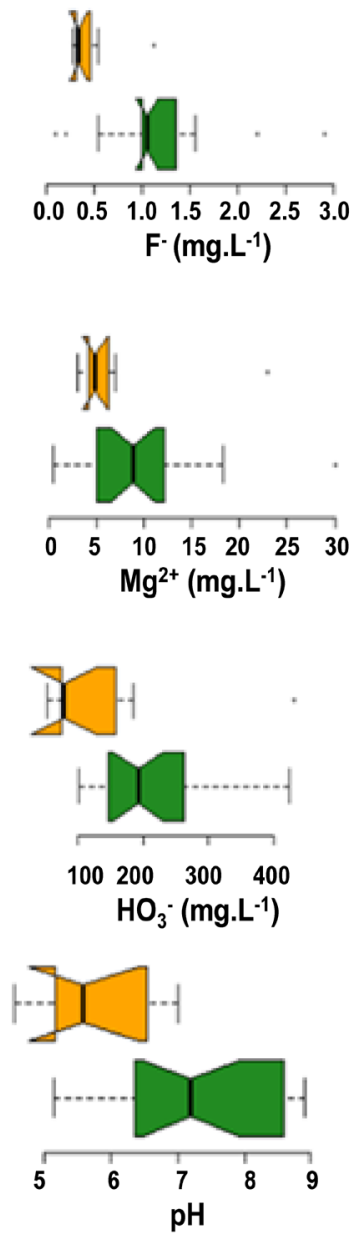
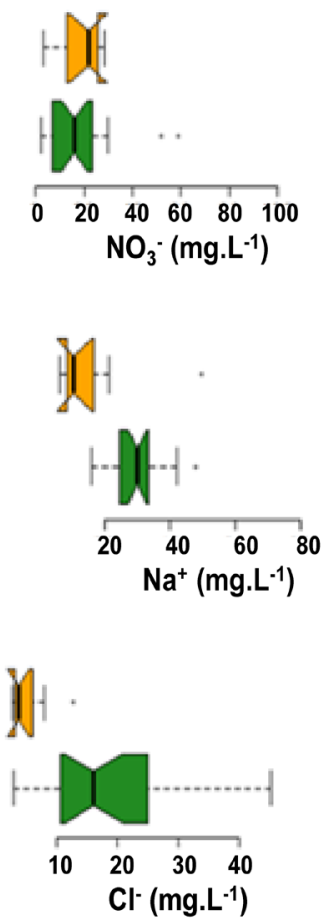

Hand dug wells

\section{Deep wells}

Figure 3. Box plots representation of the hydrochemical parameters sampled in hand dug wells and in deep wells.

Table 3. Hydrochemical average values in deep wells (D.W.) and in hand dug wells (H.D.W.) Depth in $\mathrm{m}$. All ions concentration in $\mathrm{mg} / \mathrm{l}$.

\begin{tabular}{cccccccccccccc}
\hline Parameters & Depth & $\mathrm{T}^{\circ} \mathrm{C}$ & $\mathrm{pH}$ & $\mathrm{Ca}^{2+}$ & $\mathrm{Mg}^{2+}$ & $\mathrm{Na}^{+}$ & $\mathrm{K}^{+}$ & $\mathrm{HCO}_{3}^{-}$ & $\mathrm{Cl}^{-}$ & $\mathrm{SO}_{4}^{2-}$ & $\mathrm{F}^{-}$ & $\mathrm{NO}_{3}^{-}$ & $\mathrm{TDS}$ \\
\hline DW. & 45.1 & 28.5 & 7.4 & 47.3 & 9.5 & 32.0 & 3.0 & 210.5 & 17.7 & 14.9 & 1.2 & 21.3 & 357 \\
HDW. & 10.2 & 26.3 & 5.8 & 26.3 & 7.4 & 16.7 & 5.3 & 147.1 & 5.3 & 8.1 & 0.5 & 18.4 & 235 \\
\hline
\end{tabular}


All box-plots show that concentrations of the elements are higher in deep wells than in wells dug in the alterites except for $\mathrm{K}^{+}$and $\mathrm{NO}_{3}^{-}$. This highlights the increasing mineralization of infiltrating waters and that mineralization processes are more pronounced in fractured rock. The average mineralization of dug wells water is lower (average TDS $=235 \mathrm{mg} / \mathrm{l}$ ) than that of deep wells (average TDS $=357 \mathrm{mg} / \mathrm{l})$.

\subsection{Correlation Matrice}

Pearson correlation matrice [12] was calculated between hydrochemical variables to display their respective statistical relationships (Table 4). Significant correlation coefficients, at a level of $0.05(\mathrm{p}<0.05)$, are highlighted in the table.

Strong correlations are found between $\mathrm{Ca}^{2+}$ and $\mathrm{HCO}_{3}^{-}(\mathrm{R}=0.77), \mathrm{Mg}^{2+}$ and $\mathrm{HCO}_{3}^{-} \quad(\mathrm{R}=0.68), \mathrm{Na}^{+}$and $\mathrm{HCO}_{3}^{-} \quad(\mathrm{R}=0.78), \mathrm{Ca}^{2+}$ and $\mathrm{Cl}^{-}(\mathrm{R}=0.73), \mathrm{Na}^{+}$and $\mathrm{F}^{-}(\mathrm{R}=0.73)$. Strong relationships between $\mathrm{Ca}^{2+}, \mathrm{Mg}^{2+}, \mathrm{HCO}_{3}^{-}$indicate contribution from dissolution of $\left(\mathrm{HCO}_{3}^{-}\right)_{2} \mathrm{Ca}^{2+}$ or $\left(\mathrm{HCO}_{3}^{-}\right)_{2} \mathrm{Mg}$. Relations between $\mathrm{Ca}^{2+}$ and $\mathrm{Cl}^{-}, \mathrm{Na}^{+}$and $\mathrm{HCO}_{3}^{-}$would result from complex processes discussed below.

Fluoride content is rather an important issue regarding potability of groundwater. According to the World Health Organization [13], water with a content higher than $1.5 \mathrm{mg} / \mathrm{lis}$ unsuitable for drinking. In the Wadi-Fira area, $\mathrm{F}^{-}$content ranges between $0.1 \mathrm{mg} / \mathrm{l}$ and $2.9 \mathrm{mg} / \mathrm{l}$, with an average of $1.0 \mathrm{mg} / \mathrm{l}$, indicating that at some places, the groundwater is unsuitable for drinking. It is thus important to understand the origin of $\mathrm{F}^{-}$in groundwater.

The high correlation between $\mathrm{F}^{-}$and $\mathrm{Na}^{+}$should be noticed, providing an indication on the possible source of $\mathrm{F}^{-}$. Dissolution of fluoride-bearing minerals

Table 4. Correlation matrix between variables.

\begin{tabular}{|c|c|c|c|c|c|c|c|c|c|c|c|c|}
\hline Variable & Depth & $\mathrm{T}^{\circ} \mathrm{C}$ & $\mathrm{pH}$ & $\mathrm{Ca}^{2+}$ & $\mathrm{Mg}^{2+}$ & $\mathrm{Na}^{+}$ & $\mathrm{K}^{+}$ & $\mathrm{HCO}_{3}^{-}$ & $\mathrm{Cl}^{-}$ & $\mathrm{SO}_{4}^{2-}$ & $\mathrm{F}^{-}$ & $\mathrm{NO}_{3}^{-}$ \\
\hline Depth & 1.00 & & & & & & & & & & & \\
\hline $\mathrm{T}^{\circ} \mathrm{C}$ & 0.23 & 1.00 & & & & & & & & & & \\
\hline $\mathrm{pH}$ & 0.40 & 0.37 & 1.00 & & & & & & & & & \\
\hline $\mathrm{Ca}^{2+}$ & 0.35 & 0.44 & 0.61 & 1.00 & & & & & & & & \\
\hline $\mathrm{Mg}^{2+}$ & 0.02 & 0.09 & 0.18 & 0.47 & 1.00 & & & & & & & \\
\hline $\mathrm{Na}^{+}$ & 0.31 & 0.28 & 0.21 & 0.45 & 0.51 & 1.00 & & & & & & \\
\hline $\mathrm{K}^{+}$ & -0.28 & -0.05 & -0.12 & -0.19 & 0.05 & -0.34 & 1.00 & & & & & \\
\hline $\mathrm{HCO}_{3}^{-}$ & 0.21 & 0.32 & 0.33 & 0.77 & 0.68 & 0.77 & -0.29 & 1.00 & & & & \\
\hline $\mathrm{Cl}^{-}$ & 0.43 & 0.45 & 0.56 & 0.73 & 0.30 & 0.16 & 0.19 & 0.31 & 1.00 & & & \\
\hline $\mathrm{SO}_{4}^{2-}$ & 0.31 & 0.22 & 0.40 & 0.42 & 0.45 & 0.31 & 0.42 & 0.28 & 0.61 & 1.00 & & \\
\hline $\mathrm{F}^{-}$ & 0.31 & 0.06 & 0.03 & 0.38 & 0.27 & 0.73 & -0.65 & 0.59 & 0.05 & 0.01 & 1.00 & \\
\hline $\mathrm{NO}_{3}^{-}$ & -0.06 & 0.02 & -0.20 & 0.07 & 0.10 & 0.01 & -0.12 & -0.16 & 0.11 & 0.00 & 0.07 & 1.00 \\
\hline
\end{tabular}


such as cryolite $\left(\mathrm{Na}_{3} \mathrm{AlF}_{6}\right)$ was depicted as a source of $\mathrm{F}$ - in hard rocks groundwater [14]. However further investigations are still required to deepen this issue in the Wadi-Fira area.

Cations that can exchange through ion exchange processes exhibit moderate correlation $\left(\mathrm{Na}^{+}-\mathrm{Ca}^{2+}: \mathrm{R}=0.45 ; \mathrm{Na}^{+}-\mathrm{Mg}^{2+}: \mathrm{R}=0.51\right)$. This indicates that cation exchange processes can affect the groundwater chemical composition, but are not dominant processes.

\subsection{Principal Component Analysis}

Principal Component analysis is a well-established and widely used multivariate method in hydrochemical studies. As groundwater mineralization is a multivariate concept, analyzing the hydrochemical parameters pairwise, may lead to ignore relevant relationships [15]. Thus, a Principal Component analysis ( $\mathrm{R}$ mode factor analysis, [16] [17] was undertaken in this work in order to extract significant information about analyzed data set and better display the inter-relations between the variables. A PCA may also contribute to understand the underlying geochemical reaction and hydrochemical evolution processes.

The data processed by the ACP consists of 12 hydrochemical elements measured on 31 samples from the Am Zoer and Guéréda-Iriba sites. The eigenvalues and the percentages of variance explained by each Principal Component (PC) are shown in Table 5.

The PC1 component with an expressed variance of $37.2 \%$ is the most important of all the factorial axes. The PC2 component expresses the greatest residual variance, i.e. $18.6 \%$ of the total variance. The factor plane PC1-PC2 expresses $58.8 \%$ of the cumulative variance. As can be seen on the screeplot (Figure 4), the first 2 components are sufficient to explain the variability of the data set. Thus, this PC1-PC2 plan incorporates enough significant information to highlight and explain the general trends of the studied system.

Table 5. Physicochemical variables loadings on principal components.

\begin{tabular}{cccc}
\hline & PC1 & PC2 & PC3 \\
\hline $\mathrm{T}^{\circ} \mathrm{C}$ & $\mathbf{0 . 4 8 0}$ & 0.130 & -0.077 \\
$\mathrm{pH}$ & $\mathbf{0 . 7 7 6}$ & 0.095 & -0.335 \\
$\mathrm{Ca}^{2+}$ & $\mathbf{0 . 8 1 2}$ & 0.426 & 0.064 \\
$\mathrm{Mg}^{2+}$ & 0.403 & 0.339 & 0.640 \\
$\mathrm{Na}^{+}$ & 0.285 & $\mathbf{0 . 7 8 7}$ & 0.288 \\
$\mathrm{~K}^{+}$ & 0.192 & -0.726 & 0.300 \\
$\mathrm{Cl}^{-}$ & 0.855 & -0.079 & 0.143 \\
$\mathrm{SO}_{4}^{2-}$ & $\mathbf{0 . 6 6 8}$ & -0.132 & 0.397 \\
$\mathrm{HCO}_{3}^{-}$ & 0.513 & $\mathbf{0 . 7 4 8}$ & 0.186 \\
$\mathrm{NO}_{3}^{-}$ & -0.157 & 0.009 & 0.545 \\
$\mathrm{~F}^{-}$ & 0.015 & $\mathbf{0 . 8 6 2}$ & 0.087 \\
\hline
\end{tabular}




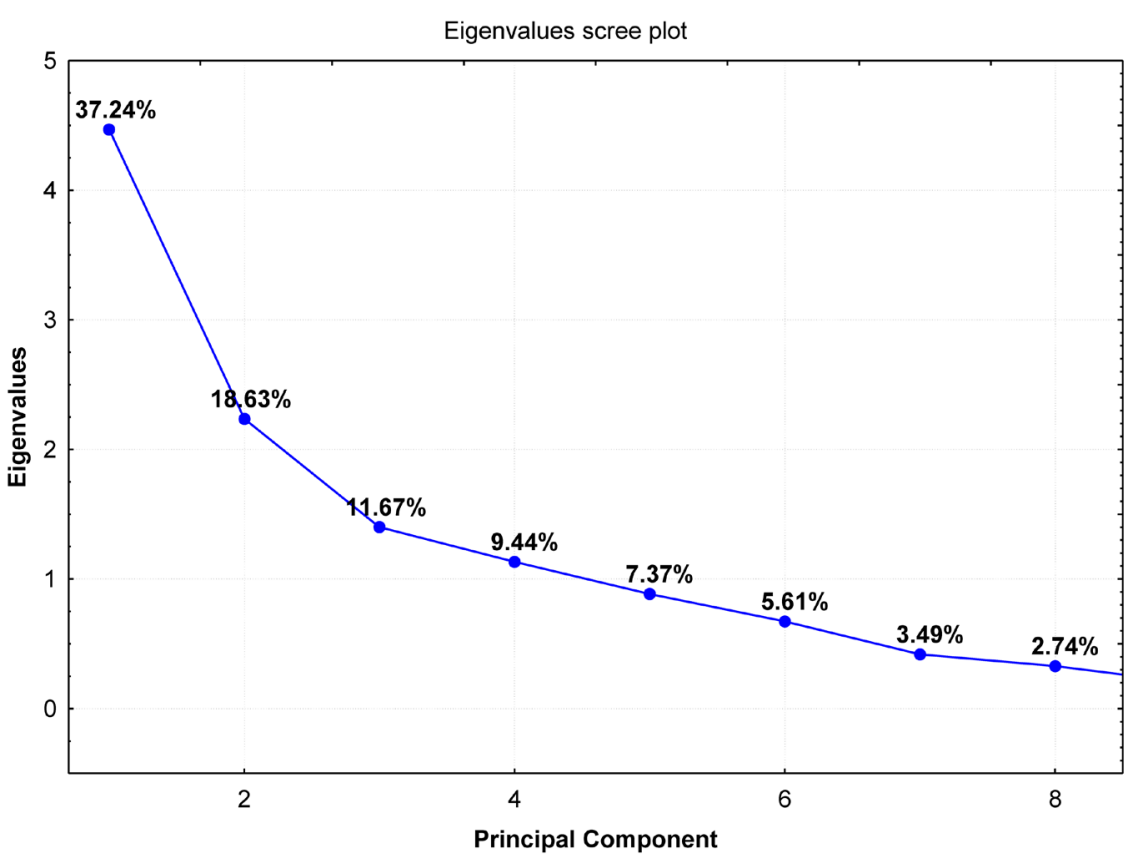

Figure 4. Principal components analysis (PCA) screeplot.

The loadings of the variables are reported in Table 5 and reported in Figure 3.

The results of the PCA are shown in Figure 5 (Projection of the hydrochemical parameters on the plane associated to components PC1 and PC2, and in Figure 6 (Projection of the samples).

The component PC1, which has the highest variance (37.2\%), is strongly associated with major chemical elements $\left(\mathrm{Ca}^{2+}, \mathrm{Mg}^{2+}, \mathrm{Na}^{+}, \mathrm{HCO}_{3}^{-}, \mathrm{Cl}^{-}\right)$. Correlations with the other elements $\left(\mathrm{F}^{-}\right.$and $\left.\mathrm{SO}_{4}^{2-}\right)$ also remain significant. It is noted that the physical parameters (temperature, $\mathrm{pH}$, depth) are also well associated with this axis. $\mathrm{NO}_{3}^{-}$and $\mathrm{K}^{+}$are poorly represented on this axis. The component PC1 thus expresses the mineralization of the water in the study region.

The second component PC2 is positively associated with $\mathrm{F}^{-}(0.71)$, and negatively with potassium $(-0.86)$.

The analysis of the projection of the variables on the factor plane (PC1-PC2) reveals that the factorial axis $\mathrm{PC} 1$ gathers almost all the elements in the positive pole with the exception of potassium $\left(\mathrm{K}^{+}\right)$and $\mathrm{NO}_{3}^{-}$. These two elements have no significant correlation with the set of variables represented in the correlation matrix. The axis $\mathrm{CP} 2$ is negatively correlated with the variables; $\mathrm{Ca}^{2+}, \mathrm{Cl}^{-}, \mathrm{SO}_{4}^{2-}$, $\mathrm{pH}, \mathrm{T}^{\circ} \mathrm{C}$, and $\mathrm{K}^{+}$, the positive pole is represented by the variables; $\mathrm{HCO}_{3}^{-}, \mathrm{Na}^{+}$, $\mathrm{Mg}^{2+}, \mathrm{F}^{-}$.

The spatial analysis of the variables of the PC1-PC2 plane makes it possible to classify, according to the affinities of the ions, two groups of variables. The first group is determined by $\mathrm{HCO}_{3}^{-}, \mathrm{Na}^{+}$and $\mathrm{F}^{-}$. The second group contains the variables $\mathrm{pH}, \mathrm{T}^{\circ} \mathrm{C}, \mathrm{SO}_{4}^{2-}$ and $\mathrm{Cl}^{-}$. The $\mathrm{Ca}^{2+}, \mathrm{Mg}^{2+}$ and Depth variables are intermediate to these 2 groups. 


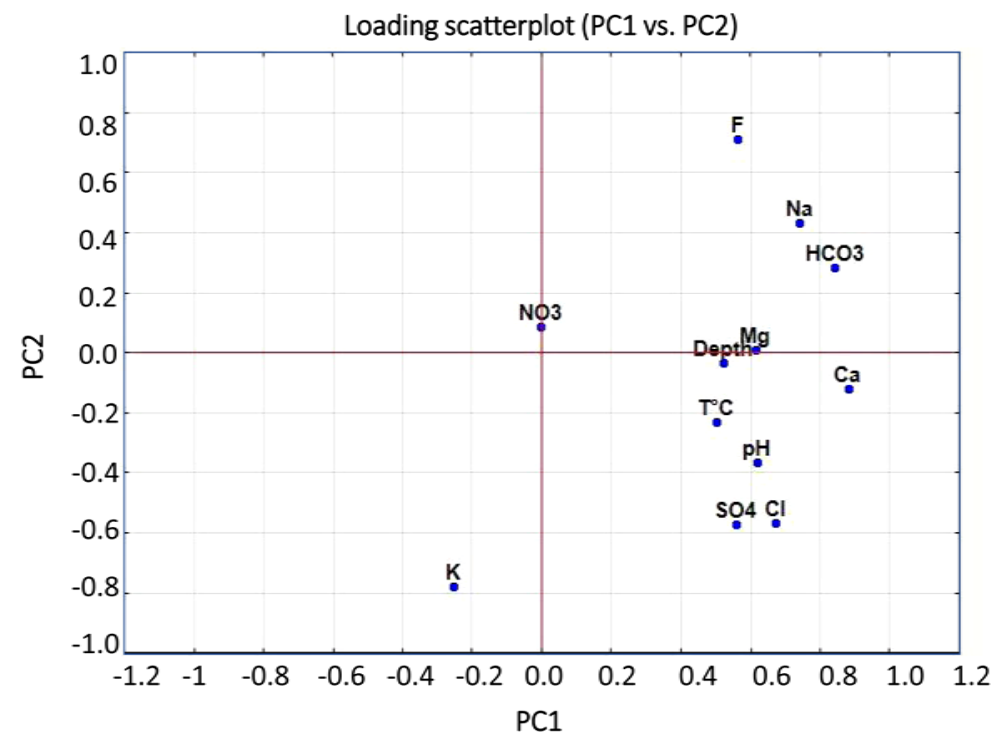

Figure 5. Principal Components Analysis (PCA). Hydrochemical variables loading plot on PC1 vs. PC2.

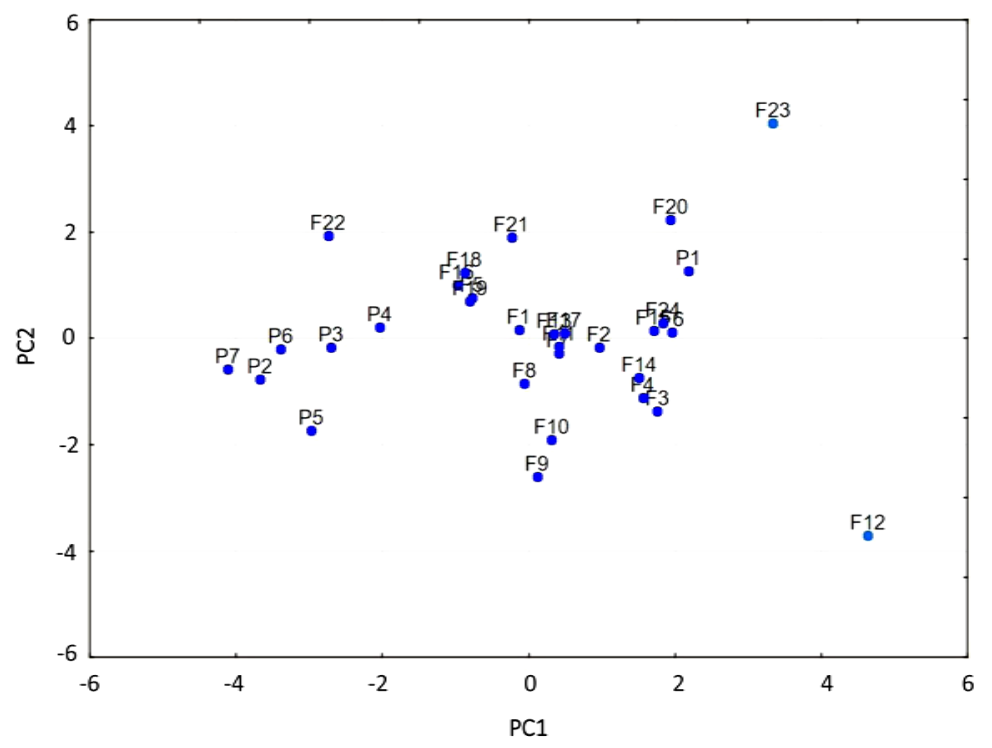

Figure 6. Plot of groundwater samples on PC1 vs. PC2.

These links between the chemical elements are in agreement with the chemical facies derived from the Piper diagram, which are $\mathrm{Ca}^{2+}-\mathrm{HCO}_{3}^{-}, \mathrm{Na}^{+}-\mathrm{HCO}_{3}^{-}$, and $\mathrm{Ca}^{2+}-\mathrm{SO}_{4}^{2-}-\mathrm{Cl}^{-}$. This shows the acid hydrolysis of the silicate minerals present in the aquifer system and at the origin of the different ions. This cluster reflects a mineralization of groundwater due mostly to the water-rock interaction.

Nitrate and potassium do not correlate with the other elements, which presuppose that they are dissolved by different mechanisms. Nitrates have a superficial origin and are evidence of anthropogenic pollution.

The projection of the samples on the plane PC1-PC2 makes it possible to dif- 
ferentiate 2 very distinct clusters according to their mineralization. Waters flowing through the fractured reservoir are more mineralized than waters in the alterites. The latter also have a lower temperature. It is interesting to note that waters in the alterites remain undifferentiated on both sites (Am Zoer and Guereda-Iriba).

On the other hand, certain discrimination can be observed on the deep waters between the two sites. Accordingly, it can be noted that most of the deep wells at Am Zoer site have warmer, more basic waters, differenciated by $\mathrm{SO}_{4}^{2-}$ and $\mathrm{Cl}^{-}$ ions. Guereda-Iriba waters are more associated with $\mathrm{Na}^{+}$and $\mathrm{HCO}_{3}^{-}$elements, and especially with $\mathrm{F}^{-}$.

The alkaline earths $\left(\mathrm{Ca}^{2+}, \mathrm{Mg}^{2+}\right)$ are present in both sites and do not discriminate between these two sites.

\subsection{Groundwater Types}

The analysis of the data from the 31 water samples shows the order of abundance of major ions as follows: calcium (51\%) and bicarbonate (80\%) are respectively the main cation and anion in the groundwater. The relative abundance in descending order for cations in groundwater is $\mathrm{Ca}^{2+}>\mathrm{Na}^{+}>\mathrm{Mg}^{2+}>\mathrm{K}^{+}$while that of the anions is $\mathrm{HCO}_{3}^{-}>\mathrm{Cl}^{-}>\mathrm{SO}_{4}^{2-}>\mathrm{NO}_{3}^{-}$. Since nitrates are not significantly correlated with any other element (indicating anthropogenic origin), they ae not considered in the Piper diagram (Figure 7).

The Piper diagram shows that the dominant anion is $\mathrm{HCO}_{3}^{-}$at both sites. For the waters of most deep wells at Am Zoer site, the dominant cation is $\mathrm{Ca}^{2+}$. Waters from dug wells and some boreholes at Guereda-Iriba, are marked by the poles $\mathrm{Ca}^{2+}$ and $\mathrm{Mg}^{2+}$. A single well (F23) at Guereda-Iriba, is characterized by the $\mathrm{Na}^{+}$pole.

The Piper diagram thus shows the following hydrochemical types:

- bicarbonate-calcium type secondary bicarbonate-sodium and bicarbonatemagnesium

- bicarbonate calcium type secondarily magnesium

- bicarbonate sodium type secondary bicarbonate-calcium and magnesium

These hydrochemical types are also represented on a semi-logarithmic Schoeller diagram [18] (Figure 8) on 10 selected samples. This diagram also shows that the $\mathrm{Ca}^{2+}$ and $\mathrm{HCO}_{3}^{-}$ions are preponderant in groundwater chemical composition and reveals more clearly that $\mathrm{Cl}^{-}$and $\mathrm{SO}_{4}^{2-}$ ions play a minor role in the mineralization of the basement aquifer groundwater.

\section{Hydrogeochemical Processes}

\subsection{Scatter Plots}

Interpretation of ionic relations in the form of scatter plots can greatly help to understand the origin of solutes and the various hydrogeochemical processes involved in the groundwater chemistry.

These scatter plots are reported in Figure 9. The plot $\mathrm{Na}^{+}$vs. $\mathrm{Cl}^{-}$(Figure 9(a)) 


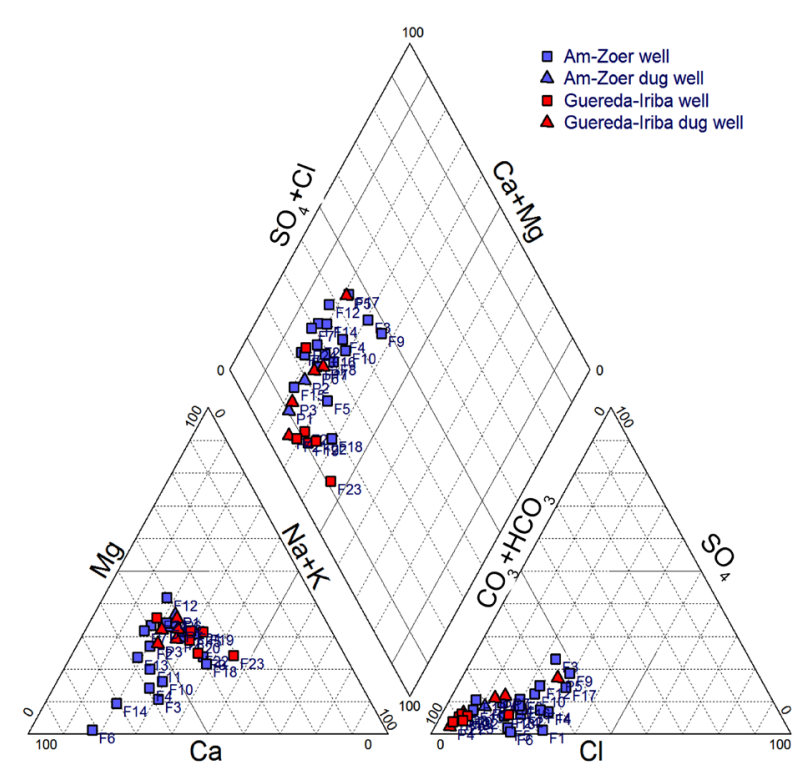

Figure 7. Trilinear Piper plot of the groundwater samples.

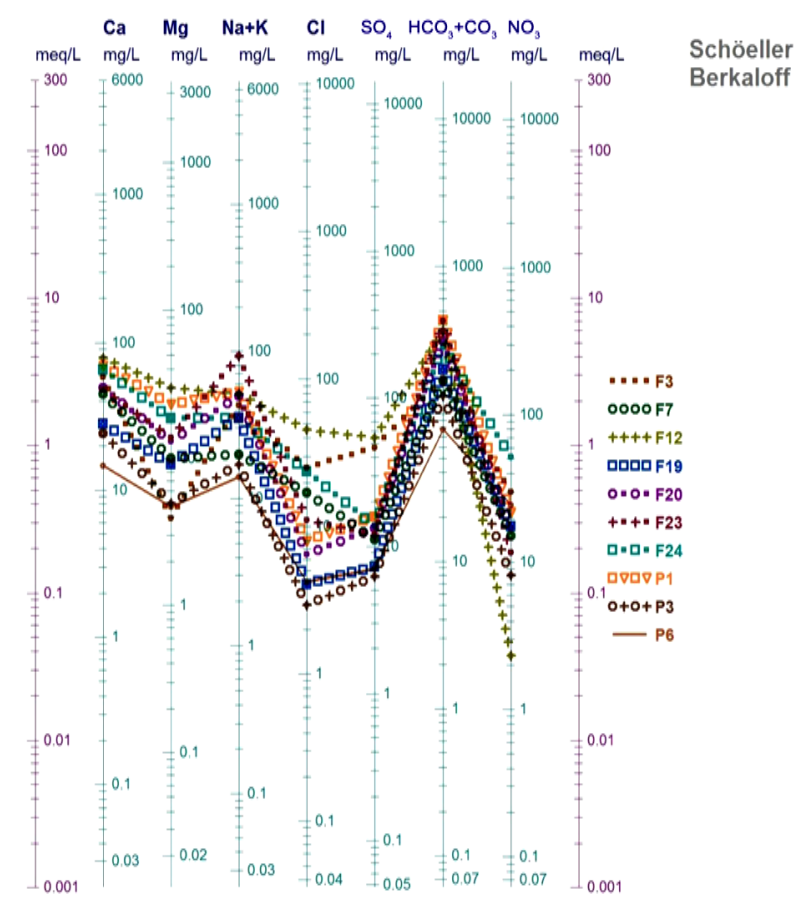

Figure 8. Plot on the Schoeller semi-logarithmic diagram of some selected groundwater samples.

shows that in all samples these elements are very weakly correlated. All samples display an enrichment with $\mathrm{Na}^{+}$compared to $\mathrm{Cl}^{-}$, indicating that these elements are not derived from the same source. The $\mathrm{Na}^{+} / \mathrm{Cl}^{-}$molar ratio is higher than 1 $\left(1.2<\mathrm{Na}^{+} / \mathrm{Cl}^{-}<13.8\right)$, reflecting that silicate weathering can be the main contributor for $\mathrm{Na}^{+}[19]$. For example albite weathering contributes $\mathrm{Na}^{+}$(see equation 01). 
The relation of $\mathrm{Na}^{+}$associated to base exchanges process is discussed below. The presence of $\mathrm{Cl}^{-}$can be attributed to another source for this ion than the dissolution of halite and could be associated, at least partly, to anthropogenic sources (agricultural fertilizers).

The source for alkaline earth elements $\left(\mathrm{Ca}^{2+}\right.$ and $\left.\mathrm{Mg}^{2+}\right)$ may be dissolution of silicate minerals (e.g., plagioclase feldspar, chlorite, or biotite), carbonates (dolomite or calcite), gypsum, and/or cation exchange of $\mathrm{Na}^{+}$for $\mathrm{Ca}^{2+}$ and $\mathrm{Mg}^{2+}$ on clay minerals. $\mathrm{HCO}_{3}^{-}$vs. $\mathrm{Ca}^{2+}$ (Figure 9(b)) displays a significant linear trend $(\mathrm{R}=0.75)$. Samples from Am Zoer site display an excess of $\mathrm{Ca}^{2+}$ while those from Guereda-Iriba plot close to 1:1 line. An essential point is that mineralization processes in the study area, are not homogeneous but display a noteworthy spatial variability.

The scatter plot $\mathrm{HCO}_{3}^{-}$vs. $\mathrm{Mg}^{2+}$ (Figure 9(c)) is characterized by a significant correlation $(\mathrm{R}=0.68)$, but also shows a deficit in $\mathrm{Mg}^{2+}$. These relations indicate that dissolution of carbonates (dolomite or calcite) is not the main source for these elements. Other sources for these ions are discussed below.

In crystalline rocks, $\mathrm{Ca}^{2+}$ is found in the feldspar network, associated with sodium and potassium, while $\mathrm{Mg}^{2+}$ is associated with iron in ferromagnesian materials (micas, amphiboles, pyroxenes, peridots). Thus excess of $\mathrm{Ca}^{2+}$ in granitic rocks (Figure $9(\mathrm{~d})$ ) may be caused by means of hydrolysis of plagioclase feldspars, as anorthite (Equation (2)):
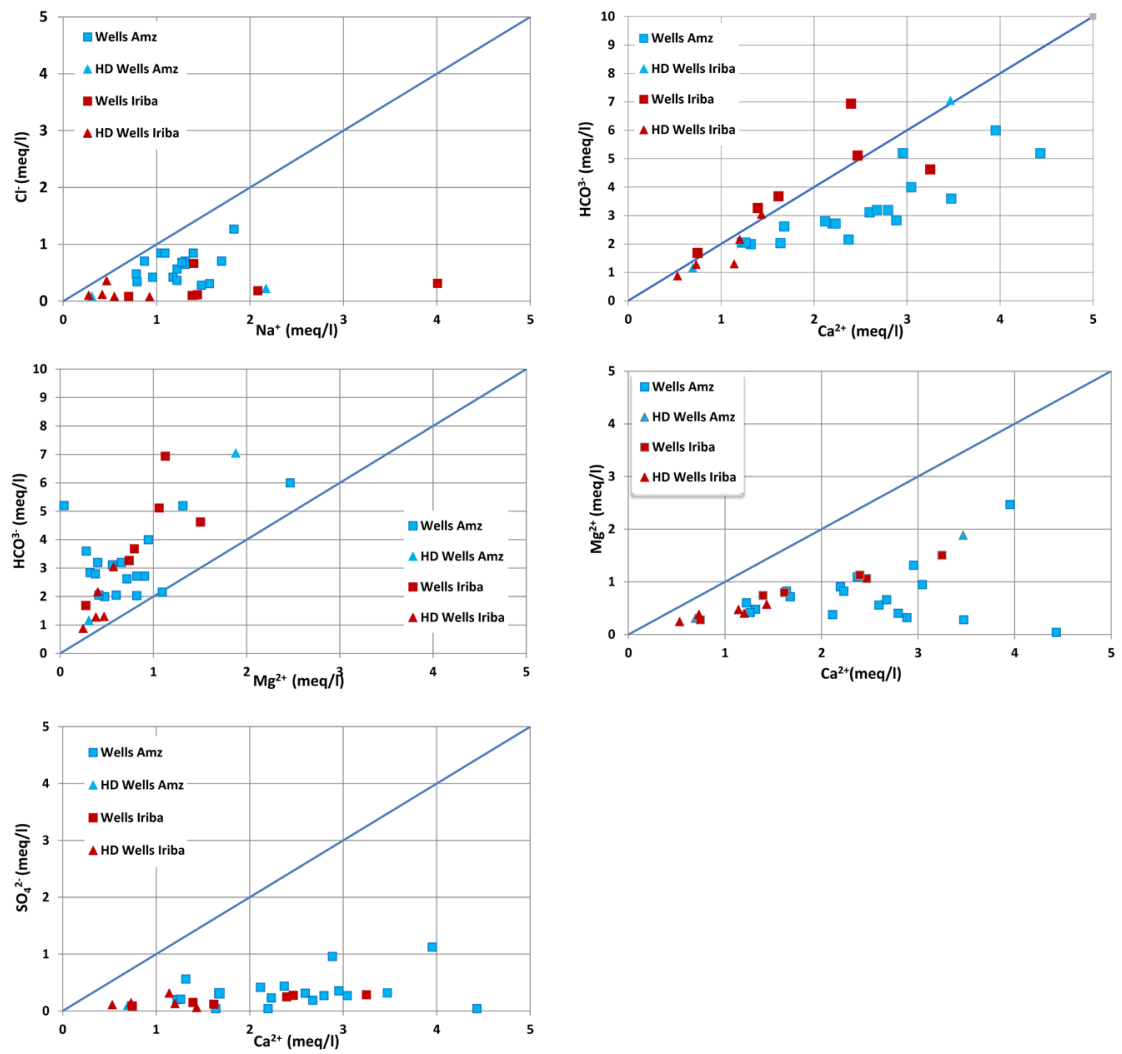

Figure 9. Scatter plots between chemical elements. 
$$
\mathrm{CaAl}_{2} \mathrm{Si}_{2} \mathrm{O}_{8}+3 \mathrm{H}_{2} \mathrm{O}+2 \mathrm{CO}_{2} \rightarrow \mathrm{Ca}^{2+}+2 \mathrm{HCO}_{3}^{-}+\mathrm{Al}_{2} \mathrm{Si}_{2} \mathrm{O}_{5}(\mathrm{OH})_{4}
$$

Weathering of ferromagnesian minerals such as biotite may be responsible for the release of $\mathrm{Mg}^{2+}$ in groundwater in basement rocks (reaction 3):

$2 \mathrm{~K}(\mathrm{Fe}, \mathrm{Mg})_{3} \mathrm{AlSi}_{3} \mathrm{O}_{10}(\mathrm{OH})_{2}+17 \mathrm{H}_{2} \mathrm{O} \rightarrow \mathrm{Si}_{2} \mathrm{O}_{5} \mathrm{Al}_{2}(\mathrm{OH})_{4}+6 \mathrm{FeO}(\mathrm{OH})+4 \mathrm{Si}(\mathrm{OH})_{4}+2 \mathrm{~K}^{+}+2 \mathrm{Mg}^{2+}+2 \mathrm{OH}^{-}$

(Biotite)

(Kaolinite) (Limonite/Goethite)

Additional geochemical processes such as the $\mathrm{Ca}^{2+} \leftrightarrow \mathrm{Mg}^{2+}$ exchanges during precipitation reactions or calcite recrystallization [20] may contribute to excess of $\mathrm{Ca}^{2+}$ compared to $\mathrm{Mg}^{2+}$ (Figure 9(d)). Figure 9(e) shows the scatter plot $\mathrm{SO}_{4}^{2-}$ vs. $\mathrm{Ca}^{2+}$. This plot displays a large deficit in $\mathrm{SO}_{4}^{2-}$. The same observation is reached when comparing $\mathrm{SO}_{4}^{2-}$ vs. $\mathrm{Mg}^{2+}$. The absence of any significant correlation indicates that the main source of these elements is not the dissolution of gypsum or any Mg-sulfate mineral. Concentrations of $\mathrm{K}^{+}$are low in Wadi-Fira groundwater (average $3.5 \mathrm{mg} / \mathrm{l}$ ), which can be expected as there are no important mineral sources of $\mathrm{K}^{+}$in these aquifers.
\end{abstract}

\title{
6.2. Mineral Saturation Indices
}

Saturation indices of minerals indicate to which extent water mineralization is controlled by equilibrium with solid phases [21]. When this indice is negative, the water is undersaturated with respect to the concerned mineral. A positive SI means that water is oversaturated regarding the mineral. When the SI value is close to 0 , water is in equilibrium with the mineral.

The software PHREEQC [22] was used to determine mineral saturation indices using the specific ionic concentrations in the water.

The saturation index of a mineral is obtained from Equation (5) [21].

$$
\mathrm{SI}=\log (\mathrm{IAP} / \mathrm{Kt})
$$

where IAP is the ion activity product of the dissociated chemical species in solution, $\mathrm{Kt}$ is the equilibrium solubility product for the chemical involved at the sample temperature.

The saturation indices of the following minerals in all water samples were evaluated: calcite, dolomite, gypsum and halite. The average values of the SI for each mineral are given in Table 6.

The saturation indices regarding calcite and dolomite have high and negative values, expressing that the groundwater is undersaturated with these minerals.

The evaporitic minerals (gypsum, halite) also have negative SI values. These results show that the minerals in question (calcite, dolomite, gypsum and halite) are not the main source of the groundwater mineralization. This is in agreement with the conclusions derived above.

\subsection{Role of Evaporation}

As the study is located in a semi-arid climatological context, it may expected that evaporation could also affect groundwater mineralization. The role of evapora 
Table 6. Average Saturation Indices (SI) of principal minerals.

\begin{tabular}{ccccc}
\hline Mineral & Calcite & Dolomite & Gypsum & Halite \\
\hline Average S.I. & -3.5 & -7.1 & -5.5 & -11.0 \\
\hline
\end{tabular}

tion has been assessed using the Gibbs diagrams [23].

Gibbs diagrams represent the ratios of $\left(\mathrm{Na}^{+}+\mathrm{K}^{+}\right) /\left(\mathrm{Na}^{+}+\mathrm{K}^{+}+\mathrm{Ca}^{2+}\right)$ and $\mathrm{Cl}^{-} /\left(\mathrm{Cl}^{-}+\mathrm{HCO}_{3}^{-}\right)$as a function of TDS. They assume that evaporation increases salinity by increasing $\mathrm{Na}^{+}$and $\mathrm{Cl}^{-}$contents in relation with increasing TDS. The diagram differentiates 3 areas highlighting various mechanisms: precipitation dominance, rocks dominance, evaporation dominance.

The plots of the hydrochemical data in Gibbs diagram are reported in Figure 10.

This figure shows that chemical weathering of rock-forming minerals is the most important functional source of dissolved elements in almost all groundwater samples. A few samples fall in the evaporation dominance area. These samples were collected from hand dug wells.

We may thus conclude that evaporation does not represent a major hydrochemical process in the study area.

\subsection{Ions Exchanges Processes}

Ions exchanges processes between the groundwater and its host rocks during its flow, can be analyzed using the plot of $\left(\mathrm{Ca}^{2+}+\mathrm{Mg}^{2+}\right)$ versus $\left(\mathrm{SO}_{4}^{2-}+\mathrm{HCO}_{3}^{-}\right)$. In this scatter diagram, the points close to the 1:1line $\left(\mathrm{Ca}^{2+}+\mathrm{Mg}^{2+}=\mathrm{SO}_{4}^{2-}+\right.$ $\mathrm{HCO}_{3}^{-}$) suggest that these ions have resulted from minerals dissolutions [24].

When groundwater has been in contact with clayey materials able to release the interchangeable alkaline-earth ions easily, then $\mathrm{Na}^{+}$contained in groundwater can exchange with these alkaline-earth ions $\left(\mathrm{Ca}^{2+}\right.$ and $\left.\mathrm{Mg}^{2+}\right)$ sorbed on the exchangeable sites. In such cases, groundwater is enriched with $\mathrm{Ca}^{2+}$ and $\mathrm{Mg}^{2+}$ and depleted in $\mathrm{Na}^{+}$. This process is called reverse ion exchange. Direct ion exchange may also occur (exchange between adsorbed $\mathrm{Na}^{+}$or $\mathrm{K}^{+}$with $\mathrm{Mg}^{2+}$ or $\mathrm{Ca}^{2+}$ in the groundwater).

Figure 11 shows the plot of $\left(\mathrm{Ca}^{2+}\right.$ and $\left.\mathrm{Mg}^{2+}\right)$ vs. $\left(\mathrm{SO}_{4}^{2-}+\mathrm{HCO}_{3}^{-}\right)$for all the samples. Most of the samples are close to the 1:1 line, demonstrating that the ion exchanges process is minor. A few samples display an excess of $\left(\mathrm{SO}_{4}^{2-}+\mathrm{HCO}_{3}^{-}\right)$ suggesting the occurrence of direct ion exchange, but with limited extent.

The fact that ions exchanges processes between groundwater and the crystalline aquifer are relatively limited, is well in agreement with the previous findings.

\section{Isotopes Analysis}

The environment isotopes of oxygen $\delta^{18} \mathrm{O}$ and hydrogen $\delta^{2} \mathrm{H}$ are excellent tracers for determining the origin of groundwater and widely used in studying the natural water circulation and groundwater movement. 

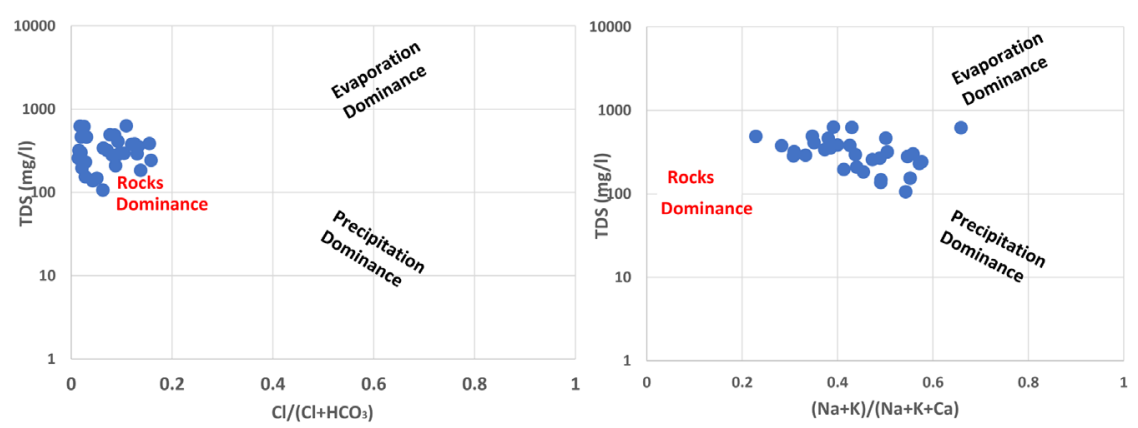

Figure 10. Gibbs diagrams.

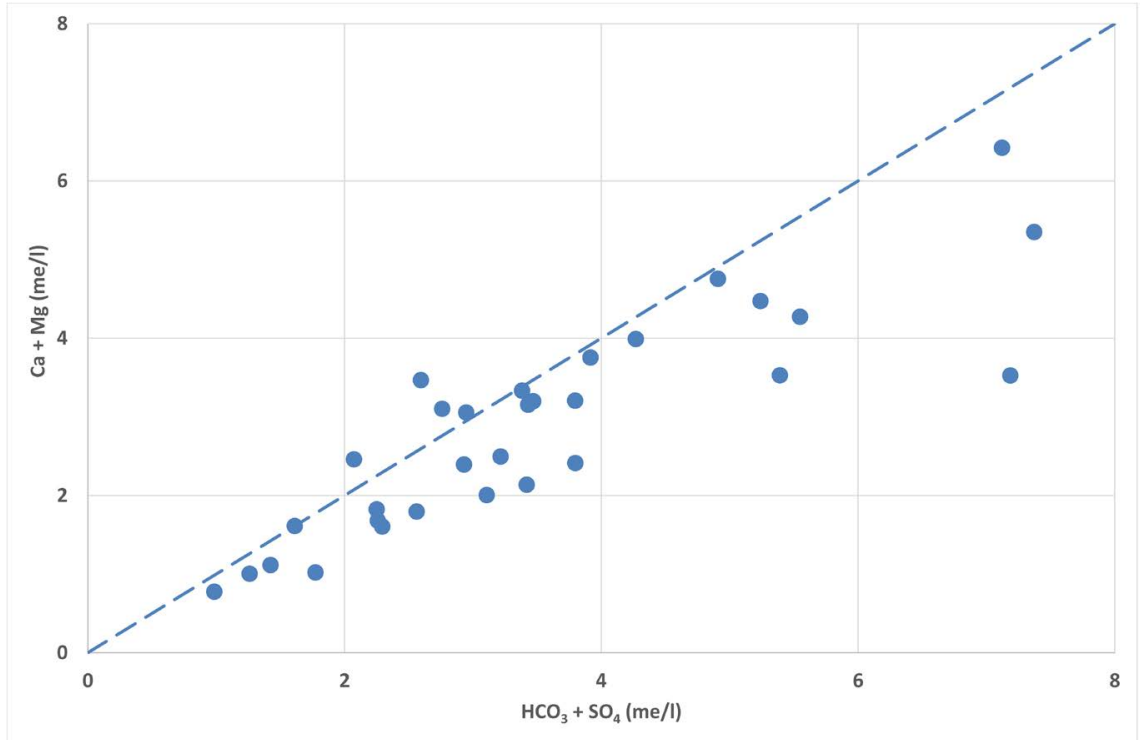

Figure 11. Diagram $(\mathrm{Ca}+\mathrm{Mg})$ vs. $\left(\mathrm{SO}_{4}+\mathrm{HCO}_{3}\right)$.

The groundwater has $\delta^{18} \mathrm{O}$ values in the range of $-5.06 \%$ to $-0.39 \%$ and $\delta^{2} \mathrm{H}$ from $-30.18 \%$ to $+6.0 \%$ (Table 7). The average values of $\delta^{18} \mathrm{O}$ and $\delta^{2} \mathrm{H}$ in the groundwater are $-3.6 \%$ and $-18.9 \%$ respectively.

The local meteoric water line (LMWL) is defined at the Geneina station (capital of West Darfur in Sudan). Its equation is:

$$
\delta^{2} \mathrm{H}=6.35 \delta^{18} \mathrm{O}+4.73
$$

The stable isotopes values are plotted in Figure 12. The global meteoric water line (GMWL) [8] is also given as reference. The GMWL is written as:

$$
\delta^{2} \mathrm{H}=8.0 \delta^{18} \mathrm{O}+10
$$

This diagram shows that the groundwater data are close to the GMWL meaning that the groundwater is in relation to modern rainfall.

This finding indicates that the groundwater recharge resource is mainly from precipitation and is weakly affected by evaporation.

Suc result is quite important since we can deduce that the renewal of groundwater is sufficiently rapid. Dating using $\mathrm{C}$ isotopes $\left({ }^{13} \mathrm{C},{ }^{14} \mathrm{C}\right)$ would help to determine the residence time of water in the aquifer system. 
Table 7. Isotope composition of groundwater in the study area.

\begin{tabular}{ccccccc}
\hline Locality & Code & Long & Lat & $\begin{array}{c}\text { Alt } \\
(\mathrm{m})\end{array}$ & $\begin{array}{c}\delta^{2} \mathrm{H} \text { vs. SMOW } \\
(\% \mathrm{o})\end{array}$ & $\begin{array}{c}\delta^{18} \mathrm{O} \text { vs. VSMOW } \\
(\%)\end{array}$ \\
\hline Am Zoer & F16 & 21.39 & 14.22 & 830 & -16.17 & -3.27 \\
Am Zoer & F17 & 21.39 & 14.22 & 823 & -19.61 & -3.67 \\
Diker & F18 & 21.07 & 14.43 & 598 & -30.18 & -5.06 \\
Iraba & P1 & 21.27 & 13.98 & 727 & -22.79 & -4.06 \\
Am Zoer & P2 & 21.39 & 14.23 & 823 & 6 & -0.39 \\
Iriba & P3 & 22.24 & 15.12 & 923 & -22.82 & -4.16 \\
Iriba & P4 & 22.24 & 15.13 & 938 & -23.6 & -4.35 \\
Iriba & P5 & 22.23 & 15.14 & 942 & -24.53 & -4.51 \\
Am nabak & P6 & 22.34 & 14.81 & 962 & -22.86 & -4.21 \\
Guéréda & P7 & 22.08 & 14.51 & 986 & -7.11 & -2.13 \\
Iriba & F19 & 22.23 & 15.09 & 914 & -24.79 & -4.51 \\
Iridimi & F20 & 22.11 & 15.13 & 950 & -23.44 & -4.12 \\
Iridimi & F21 & 22.12 & 15.12 & 954 & -20.56 & -3.86 \\
Guéréda & F22 & 22.07 & 14.51 & 991 & -14.37 & -3.13 \\
Guéréda & F23 & 22.11 & 14.51 & 1001 & -15.12 & -3.03 \\
kounogo & F24 & 21.95 & 14.48 & 965 & -19.81 & -3.74 \\
\hline & & & & & & \\
\hline
\end{tabular}

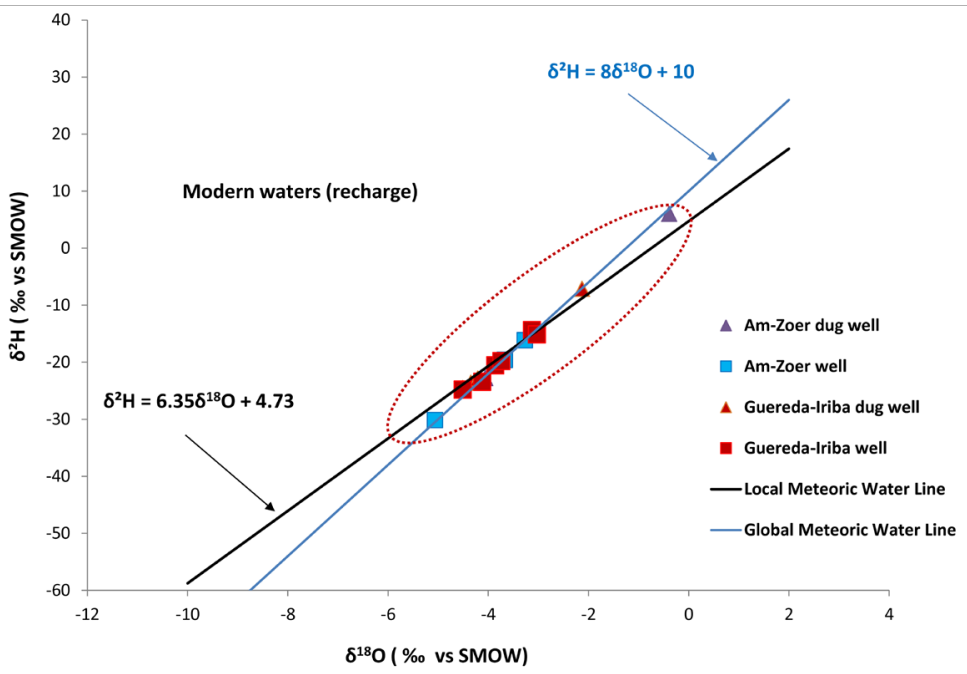

Figure 12. Stable isotopes diagram.

\section{Summary and Conclusions}

Groundwater is a vital resource for the Wadi-Fira region in eastern Chad. The water needs of this region of Chad have increased dramatically in recent years, given the increase in population and the development of agricultural and urban activities caused by an influx of refugees from neighboring Darfur. 
The aquifer system exploited in this region is represented by the rocks of the crystalline basement. Groundwater is exploited using wells dug in the alterites and deep wells penetrating the fractured rocks. However, the available knowledge about the hydrogeology and the water quality of this system is still very low.

The objective of this work was to study the processes of groundwater mineralization and recharge mechanisms. Hydrochemical and isotopic analyses were carried out on water samples collected during two field campaigns organized in 2011 and 2015. The results of the analyses and their interpretations have shown that groundwater is on the whole fairly gentle. However, the mineralization of the deep waters of the fractured crystalline reservoir is more important than that of the waters of the alterites. The predominant process of mineralization is the interaction between water and rock and the solution of minerals. Other processes intervene (basic exchanges, precipitation, evaporation), but their impact is moderate. The isotopic data have shown that the groundwater of this system is related to modern precipitation. Recharging the system is relatively fast. This study has allowed to significantly improve knowledge on this complex system and laid the bases to consider a more rational exploitation of the resource.

\section{References}

[1] Sonet, J. (1963) Explanatory Booklet on the Niéré Sheet. Reconnaissance Geological Map of Chad at 1/500,000. BRGM, Orléans.

[2] Isseini, M. (2011) Crustal Growth and Differentiation during the Neoproterozoic Example of the Pan-African Domain of Mayo Kebbi in Southwestern Chad. PhD Thesis, University Henri Poincaré, Nancy.

[3] Wyns, R., Baltassat, J.M., Lachassagne, P., Legchenko, A., Vairon, J. and Mathieu, F. (2004) Application of SNMR Soundings for Groundwater Reserves Mapping in Weathered Basement Rocks (Brittany, France). Bulletin de la Société Géologique de France, 175, 21-34. https://doi.org/10.2113/175.1.21

[4] Chilton, P.J. and Foster, S.S.D. (1995) Hydrogeological Characterization and Water-Supply Potential of Basement Aquifers in Tropical Africa. Hydrogeology Journal, 3, 36-49. https://doi.org/10.1007/s100400050061

[5] Maréchal, J.C., Dewandel, B., Subrahmanyam, K. and Torri, R. (2003) Review of Specific Methods for the Evaluation of Hydraulic Properties in Fractured Hard-Rock Aquifers. Current Science, 85, 516.

[6] Acworth, R.I. (1987) The Development of Crystalline Basement Aquifers in a Tropical Environment. Quarterly Journal of Engineering Geology, 20, 265-272. https://doi.org/10.1144/GSL.QJEG.1987.020.04.02

[7] Cho, M., Ha, K.-M., Choi, Y.-S., Kee, W.-S., Lachassagne, P. and Wyns, R. (2003) Relationship between the Permeability of Hard-Rock Aquifers and Their Weathered Cover Based on Geological and Hydrogeological Observation in South Korea. IAH Conference on Groundwater in Fractured Rocks, Prague, 15-19 September 2003, 41-43.

[8] Craig, H. (1961) Isotopic Variations in Meteoric Waters. Science, 133, 1702-1703. https://doi.org/10.1126/science.133.3465.1702

[9] Piper, A.M. (1944) A Graphic Procedure in the Geochemical Interpretation of Wa- 
ter Analyses. Transactions-American Geophysical Union, 25, 914-923.

[10] IAEA (2007) Global Network of Isotopes in Precipitation (GNIP) Database IAEA/WMO, Vienna, Austria. https://nucleus.iaea.org/Pages/GNIPR.aspx

[11] Langmuir, D. (1997) Aqueous Environmental Geochemistry. Prentice Hall, Upper Saddle River.

[12] Swan, A.R.H. and Sandilands, M. (1995) Introduction to Geological Data Analysis. Blackwell, Oxford.

[13] WHO (1984) Guidelines for Drinking Water Quality. World Health Organization, Geneva.

[14] Furi, W., Razack, M., Abiye, T.A., Kebede, S. and Legesse, D. (2012) Hydrochemical Characterization of Complex Volcanic Aquifers in a Continental Rifted Zone: The Middle Awash Basin, Ethiopia. Hydrogeology Journal, 20, 385-400. https://doi.org/10.1007/s10040-011-0807-1

[15] Steinhorst, R.K. and Williams, R.E. (1985) Discrimination of Groundwater Sources using Cluster Analysis, MANOVA, Canonical Analysis and Discriminant Analysis. Water Resources Research, 21, 1149-1156.

[16] Dawdy, D.R. and Feth, J.H. (1967) Application of Factor Analysis in Study of Chemistry of Groundwater Quality, Mojave River Valley, California. Water Resources Research, 3, 505-510.

[17] Dalton, M.G. and Upchurch, S.B. (1978) Interpretation of Hydrochemical Facies by Factor Analysis. Ground Water, 16, 228-233.

[18] Schoeller, H. (1967) Geochemistry of Groundwater. An International Guide for Research and Practice. UNESCO, Chap 15, 1-18.

[19] Meybeck, M. (1987) Global Chemical Weathering of Surficial Rocks Estimated from River Dissolved Loads. American Journal of Science, 287, 401-428. https://doi.org/10.2475/ajs.287.5.401

[20] Edmunds, W.M., Kay, R.L.F., Miles, D.L. and Cook, J.M. (1987) The Origin of Saline Groundwaters in the Carnmenellis Granite, Cornwall (UK): Further Evidence from Minor and Trace Elements. In: Fritz, P. and Frape, S.K., Eds., Saline Water and Gases in Crystalline Rocks, Geological Association of Canada Special Paper 33, Geological Association of Canada, St. John's, 127-143.

[21] Appelo, C.A.J. and Postma, D. (1996) Geochemistry, Groundwater and Pollution. Balkema, Rotterdam, 536.

[22] Parkhurst, D.L. and Appelo, C.A.J. (1999) User's Guide to PHREEQC (Version 2)-A Computer Program for Speciation, Batch-Reaction, One-Dimensional Transport, and Inverse Geochemical Calculations. United States Geological Survey, Water Resources Investigations Report 99-4259, Washington DC, 326.

[23] Gibbs, R. (1970) Mechanism Controlling World River Water Chemistry. Science, 170, 1088-1090. https://doi.org/10.1126/science.170.3962.1088

[24] Fisher, R.S. and Mulican III, W.F. (1997) Hydrochemical Evolution of Sodium-Sulfate and Sodium-Chloride Groundwater beneath the Northern Chihuahuan Desert, Trans-Pecos, Rexas, USA. Hydrogeology Journal, 10, 455-474. 